\title{
Determination of Various Physical Properties of Okra Seeds
}

\author{
Falguni Rathore and Atul Kumar Shrivastava* \\ Department of Farm Machinery and Power Engineering, College of Agricultural \\ Engineering, Jawaharlal Nehru Krishi Vishwa Vidhyalaya, Jabalpur (M.P.), India \\ *Corresponding author
}

\section{A B S T R A C T}

\begin{tabular}{|l|}
\hline Ke y w o r d s \\
Okra seed, \\
$\begin{array}{l}\text { Spehericity, } \\
\text { Geometry mean } \\
\text { diameter, Angle of } \\
\text { repose }\end{array}$ \\
\hline Article Info \\
$\begin{array}{l}\text { Accepted: } \\
\text { 26 January } 2021 \\
\text { Available Online: } \\
\text { 10 February } 2021\end{array}$ \\
\hline
\end{tabular}

\section{Introduction}

Bhindi or lady's finger is also called okra (Abelmoschus esculents) belonging to Malvaceae family. One of the most important vegetable crop cultivated in various states of India. Several species of the genus Abelmoschus are grown in many parts of the world among them Abelmoschus esculentus is most commonly grown in Asia. It has a great commercial demand due to its nutritional values. India occupies first position in okra production in the world $\mathbf{7 3 \%}$ of world production). The major okra producing states are Andhra Pradesh, Bihar, West Bengal, Odisha. In India, its sown area was 513 thousand hectares with a production of 6170 thousand metric tonnes during 2018-19.

Okra has a relatively good nutritional value and is a good complement in developing countries where there is often a great alimentary imbalance. It is a good source of vitamin C $(30 \mathrm{mg} / 100 \mathrm{~g})$, protein (2.2 percent), carbohydrates (9.7 percent), fiber (1 percent), fats, minerals, iodine. Fresh fruits rich in calcium $(90 \mathrm{mg})$, iron $(1.5 \mathrm{mg}), \mathrm{Mg}$ (43 mg), P (56 mg), moisture content (86.9 percent) in $100 \mathrm{~g}$ of fresh fruit.

The physical properties data are required for the development of its metering mechanism 
of planter. The data can also be used for designing of its handling, processing, and storage structure. Separation of unwanted material from seed is easy through oscillating chaffers when the size, shape, and density of the seed are known. The angle of repose affects the design of mass flow structures. The study was to measure physical properties of okra seed which includes size, shape, bulk density, true density, angle of repose, porosity, and weight of one thousand seeds.

\section{Materials and Methods}

\section{Sample preparation}

The two varieties were selected of okra seed i.e. Arka and Gujrat-5. The selected seeds were cleaned from foreign material, damaged seeds, and impurities by passes through a metal screen and by manual picking.

\section{Determination of Physical Properties}

Seed properties essential for the development of the metering, processing, and storage systems, were identified and determined. Different properties of Okra such as moisture content, length, width, thickness, size, sphericity, angle of repose, bulk density, true density, porosity, and angle of repose were determined by using standard techniques.

The moisture content of the selected seed was determined by the oven dying method placed at $105^{\circ} \mathrm{C}$. To determine the effect of moisture content on different physical properties of okra, the moisture content was determined by:-

Moisture content
weig 4 t of moistwre

(dB) $\% \quad=$

$\overline{\text { weig } \square \text { t of dry matter }} \times 100$

The three moisture content of the seeds were found to be $6.10 \%, 8.20 \%$, and $11.50 \%$ on dry basis.

\section{Size of Okra Seed}

The primary property of any seed is seed size. The purpose of seed size is to design of cell of the metering device. The seed size was specified by its length, width, and thickness. The seed size was determined by using vernier caliper with the least count of 0.01 $\mathrm{mm}$. For the measurement, randomly 50 seeds were selected.

The size of the seeds was calculated with the following formula proposed by

$\mathrm{S}_{\mathrm{z}}=(\mathrm{L} \times \mathrm{W} \times \mathrm{T})^{1 / 3}$

Where $\mathrm{L}=$ Length, $\mathrm{mm}$; and $\mathrm{b}=$ breadth, $\mathrm{mm}$; and $\mathrm{T}=$ Thickness, $\mathrm{mm}$

\section{Sphericity}

Sphericity $(\varnothing)$ is defined as the ratio of surface area $(\mathrm{S})$ of having the same volume (V) as that of the particle to the $S$ of the particle. The sphericity is expressed in percent:-

$\emptyset=\frac{(L X B X T)^{1 / 8}}{L}$

\section{Bulk density}

Bulk density $\left(\mathrm{B}_{\mathrm{d}}\right)$ of okra seed was determined by taking the weight of okra in a fixed volume

$\mathrm{Bd}=\frac{W}{V}$

Where,

$\mathrm{W}=$ Weight of seed sample, $\mathrm{g}$;

$\mathrm{V}=$ Volume of sample box, $\mathrm{cm}^{3}$

\section{True density}

The True density (Td) is defined as the ratio of mass of grain to the solid volume occupied. 
It is determined using liquid displacement technique.

$$
\mathrm{Td}=\frac{M}{s}
$$

\section{Porosity}

Porosity was calculated as the ratio of the difference in the grain and bulk densities to grain density and expressed in percentage.

Porosity $(\varepsilon) \%=1-\frac{B_{d d}}{T_{d}}$

Where,

$\mathrm{BD}=$ Bulk density

$\mathrm{TD}=$ True density

\section{Angle of Repose}

The angle of repose was measured by the slump cone method. A cylinder was filled up to the top with a sample and inverted on a plane (paper) surface. The paper was taken out gradually and cylinder was raised vertically, thus conical shape of the material was formed. The angle of repose was calculated by using the following expression.

$$
\emptyset=\tan -1 \frac{2\left(H_{a}-H_{b}\right)}{D_{b}}
$$

\section{Results and Discussion}

The result based on the different physical property of two different variety of okra seed are given below:-

\section{Okra-Arka}

\section{Seed dimension}

In table 1 , the average dimension of length, width, thickness, geometry mean diameter and sphericity were $5.27 \mathrm{~mm}, 4.67 \mathrm{~mm}, 3.98$ $\mathrm{mm}, 4.53 \mathrm{~mm}$, and $0.86 \mathrm{~mm}$ respectively at the 6.10 percent moisture content. It shows that the dimension increased with the increase of moisture content. At the moisture content was increased from 6.10 percent to 8.20 percent, the mean length, width, thickness, geometry mean diameter, and sphericity were $6.14 \mathrm{~mm}, 5.38 \mathrm{~mm}, 4.72 \mathrm{~mm}, 5.29 \mathrm{~mm}$, and $0.86 \mathrm{~mm}$ respectively whereas moisture content was 11. 50 percent, the average length, width, thickness, geometry mean diameter, and sphericity were $7.29 \mathrm{~mm}, 6.26$ $\mathrm{mm}, 5.40 \mathrm{~mm}, 6.15 \mathrm{~mm}$, and $0.85 \mathrm{~mm}$ respectively.

It shows that table 2, the average bulk density, true density, porosity, and angle of repose were $0.77 \mathrm{~g} / \mathrm{cm}^{3}, 1.30 \mathrm{~g} / \mathrm{cm}^{3}, 40.62$, and $26.92^{\circ}$ at the 6.10 percent moisture content respectively. At the moisture content was increased from 6.10 percent to 11.50 percent, the bulk density, true density, and porosity was decreased. It was observed that the angle of repose was increased from $26.92^{\circ}$ to $28.52^{\circ}$ with the moisture content increased from 6.10 percent to 11.50 percent respectively.

Figure-1 shows that the size of seed was increased with an increase of moisture content. The relationship between moisture content and seed size was found to be logarithmic which expressed $\mathrm{R}^{2}$ values. The values of $\mathrm{R}^{2}$ for length, width, and thickness are $0.993,0.996$, and 0.994 respectively.

In figure -2 shows that the porosity was continuously decreased with an increased moisture content. The relationship between moisture content and porosity is expressed by logarithmic.

$\mathrm{P}=1.4 \mathrm{x}+42.13$

$\mathrm{R}^{2}=0.981$

In figure-3, it can be seen that the angle of repose is linearly increased with an increased moisture content. 
$Y=0.925 x+25.887$

$\mathrm{R}^{2}=0.960$

\section{Okra gujrat}

In table 3, the average length, width, and thickness were $3.39,2.40$, and $1.57 \mathrm{~mm}$ at the 6.10 percent moisture content respectively. The moisture content increased from 6.10 percent to 11.50 percent with also increased length $(5.68 \mathrm{~mm})$, width $(4.95 \mathrm{~mm})$, and thickness $(4.29 \mathrm{~mm})$. The geometry mean diameter in the range was $2.30 \mathrm{~mm}$ to 4.85 $\mathrm{mm}$ at the moisture content from 6.10 percent to 11.50 percent. The sphericity was 0.69 to $0.86 \mathrm{~mm}$ with the moisture content 6.10 to 11.50 percent.

It shows that in table 4 , the bulk density was decreased from 0.645 to $0.569 \mathrm{~g} / \mathrm{cm}^{3}$ with the moisture content increased from 6.10 to 11.50 percent. The true density was also decreased with increased moisture content. The porosity was in the range of 41.99 to 37.28 at the same moisture content. The angle of repose was increased from $27.21^{\circ}$ to $28.13^{\circ}$ at the moisture content 6.10 to 11.50 percent respectively.

Table.1 Average dimensions of seeds with moisture content

\begin{tabular}{|c|c|c|c|c|c|c|}
\hline $\begin{array}{c}\text { Moisture } \\
\text { Content \% }\end{array}$ & & $\begin{array}{c}\text { Length, } \\
\text { mm }\end{array}$ & $\begin{array}{c}\text { Width, } \\
\text { mm }\end{array}$ & $\begin{array}{c}\text { Thickness, } \\
\text { mm }\end{array}$ & $\begin{array}{c}\text { Geometric mean } \\
\text { diameter, mm }\end{array}$ & $\begin{array}{c}\text { Sphericity, } \\
\text { mm }\end{array}$ \\
\hline \multirow[t]{3}{*}{6.10} & Mean & 5.27 & 4.67 & 3.98 & 4.53 & 0.86 \\
\hline & S.D & 0.49 & 0.36 & 0.30 & 0.29 & 0.05 \\
\hline & CV \% & 9.34 & 7.79 & 7.66 & 6.37 & 5.79 \\
\hline \multirow[t]{3}{*}{8.20} & Mean & 6.14 & 5.38 & 4.72 & 5.29 & 0.86 \\
\hline & S.D & 0.40 & 0.35 & 0.36 & 0.25 & 0.04 \\
\hline & CV \% & 6.49 & 6.58 & 7.69 & 4.66 & 4.89 \\
\hline \multirow[t]{3}{*}{11.50} & Mean & 7.29 & 6.26 & 5.40 & 6.15 & 0.85 \\
\hline & S.D & 0.43 & 0.34 & 0.36 & 0.21 & 0.04 \\
\hline & CV \% & 5.88 & 5.49 & 6.66 & 3.45 & 5.08 \\
\hline
\end{tabular}

Table.2 Average of bulk density, true density, porosity and angle of repose with moisture content

\begin{tabular}{|c|c|c|c|c|c|}
\hline $\begin{array}{c}\text { Moisture } \\
\text { Content, \% }\end{array}$ & & $\mathrm{BD}, \mathrm{g} / \mathrm{cm}^{3}$ & $\begin{array}{l}\text { TD, } \\
\text { g/cm }\end{array}$ & Porosity & $\begin{array}{c}\text { Angle of Repose, } \\
\text { degree }\left({ }^{\circ}\right)\end{array}$ \\
\hline \multirow[t]{3}{*}{6.10} & Mean & 0.77 & 1.30 & 40.62 & 26.92 \\
\hline & S.D & 0.01 & 0.00 & 0.61 & 0.20 \\
\hline & CV \% & 1.05 & 0.38 & 1.50 & 0.75 \\
\hline \multirow[t]{3}{*}{8.20} & Mean & 0.74 & 1.23 & 39.55 & 27.52 \\
\hline & S.D & 0.00 & 0.02 & 0.70 & 0.32 \\
\hline & CV \% & 0.21 & 1.37 & 1.78 & 1.17 \\
\hline \multirow[t]{3}{*}{11.50} & Mean & 0.62 & 1.01 & 37.88 & 28.52 \\
\hline & S.D & 0.01 & 0.00 & 0.74 & 0.34 \\
\hline & CV \% & 1.12 & 0.32 & 1.95 & 1.17 \\
\hline
\end{tabular}


Table.3 Average dimensions of seeds with moisture content

\begin{tabular}{|c|c|c|c|c|c|c|}
\hline $\begin{array}{c}\text { Moisture } \\
\text { Content, \% }\end{array}$ & & $\begin{array}{c}\text { Length, } \\
\mathbf{m m}\end{array}$ & $\begin{array}{c}\text { Width, } \\
\mathbf{m m}\end{array}$ & $\begin{array}{c}\text { Thickness, } \\
\mathbf{m m}\end{array}$ & $\begin{array}{c}\text { Geometric } \\
\text { mean } \\
\text { diameter, mm }\end{array}$ & $\begin{array}{c}\text { Sphericity, } \\
\text { mm }\end{array}$ \\
\hline \multirow{2}{*}{$\mathbf{6 . 1 0}$} & Mean & 3.39 & 2.40 & 1.57 & 2.30 & 0.69 \\
\cline { 2 - 7 } & S.D & 0.49 & 0.37 & 0.28 & 0.26 & 0.07 \\
\cline { 2 - 7 } & CV \% & 14.32 & 15.42 & 17.78 & 11.11 & 10.91 \\
\hline \multirow{2}{*}{$\mathbf{8 . 2 0}$} & Mean & 5.58 & 4.53 & 3.69 & 4.46 & 0.80 \\
\cline { 2 - 7 } & S.D & 0.32 & 0.27 & 0.26 & 0.20 & 0.04 \\
\cline { 2 - 7 } & CV \% & 5.71 & 5.95 & 7.17 & 4.42 & 4.47 \\
\hline \multirow{2}{*}{$\mathbf{1 1 . 5 0}$} & Mean & 5.68 & 4.95 & 4.29 & 4.85 & 0.86 \\
\cline { 2 - 7 } & S.D & 0.53 & 0.47 & 0.52 & 0.43 & 0.05 \\
\cline { 2 - 7 } & CV \% & 9.40 & 9.43 & 12.03 & 8.80 & 5.54 \\
\hline
\end{tabular}

Table.4 Average dimension of bulk density, true density, porosity and angle of repose with moisture content

\begin{tabular}{|c|c|c|c|c|c|}
\hline $\begin{array}{c}\text { Moisture } \\
\text { Content, \% }\end{array}$ & & $\mathrm{BD}, \mathrm{gm} / \mathrm{cm}^{3}$ & $\begin{array}{c}\text { TD, } \\
\mathrm{gm} / \mathrm{cm}^{3}\end{array}$ & Porosity & $\begin{array}{c}\text { Angle of } \\
\text { Repose, Degree }\end{array}$ \\
\hline \multirow[t]{3}{*}{6.10} & Mean & 0.645 & 1.112 & 41.993 & 27.210 \\
\hline & S.D & 0.01 & 0.01 & 1.13 & 0.30 \\
\hline & CV \% & 1.71 & 0.86 & 2.68 & 1.10 \\
\hline \multirow[t]{3}{*}{8.20} & Mean & 0.597 & 1.014 & 41.104 & 27.580 \\
\hline & S.D & 0.00 & 0.01 & 0.48 & 0.33 \\
\hline & CV \% & 0.77 & 0.63 & 1.17 & 1.18 \\
\hline \multirow[t]{3}{*}{11.50} & Mean & 0.569 & 0.907 & 37.286 & 28.130 \\
\hline & S.D & 0.01 & 0.00 & 0.86 & 0.16 \\
\hline & $\mathrm{CV} \%$ & 0.88 & 0.50 & 2.31 & 0.56 \\
\hline
\end{tabular}

Fig.1 Effect of moisture content on length, width, and thickness of okra seeds

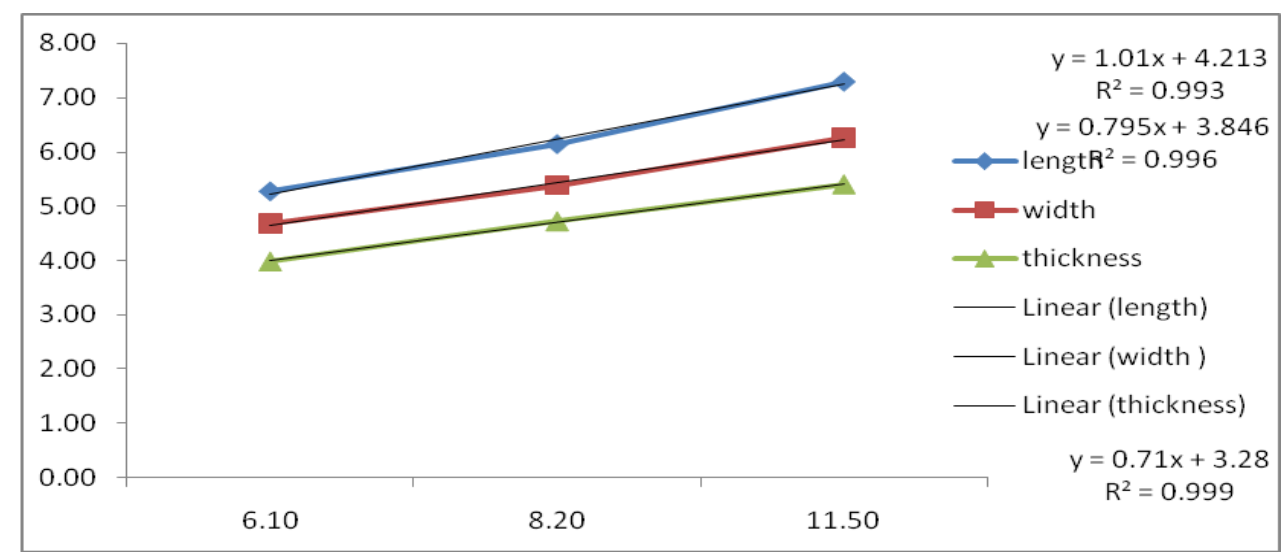


Fig.2 Effect of moisture content on porosity

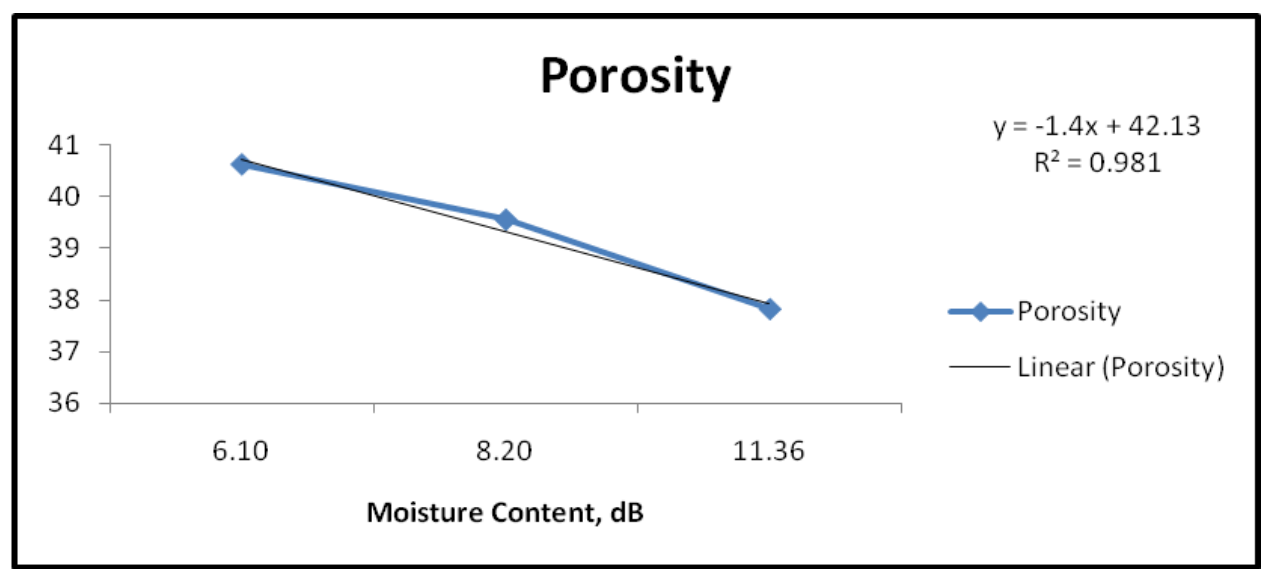

Fig.3 Effect of moisture content on angle of repose

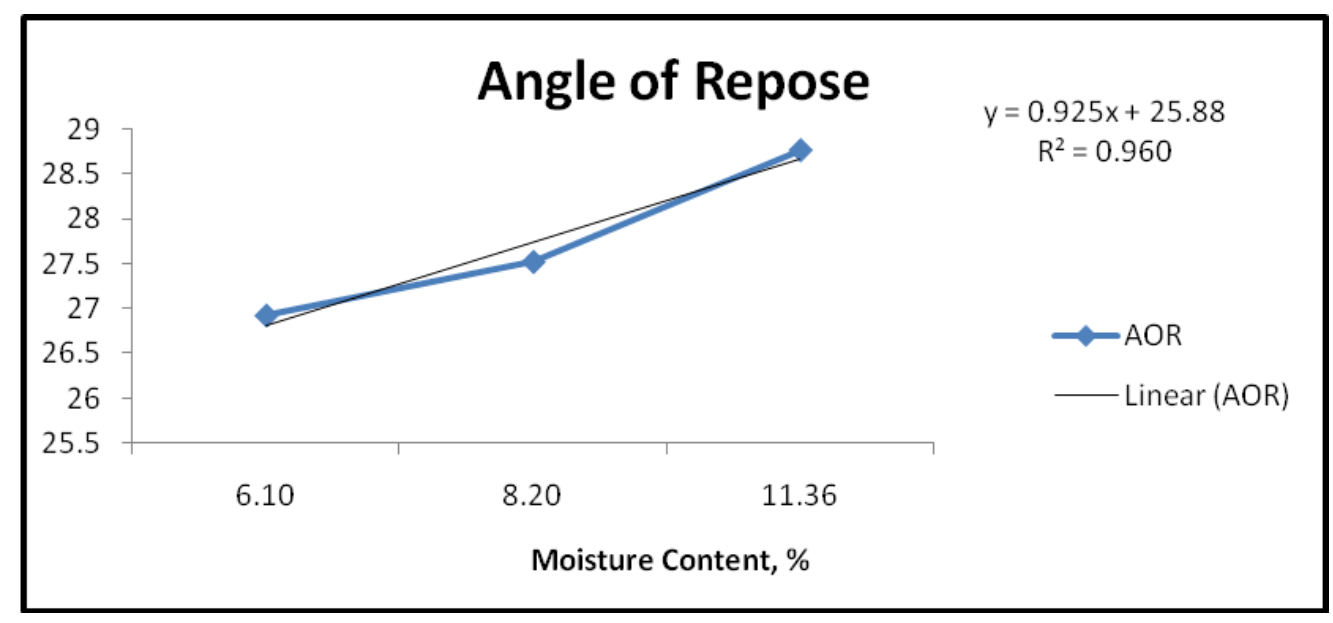

Fig.4 Effect of moisture content on seed dimensions

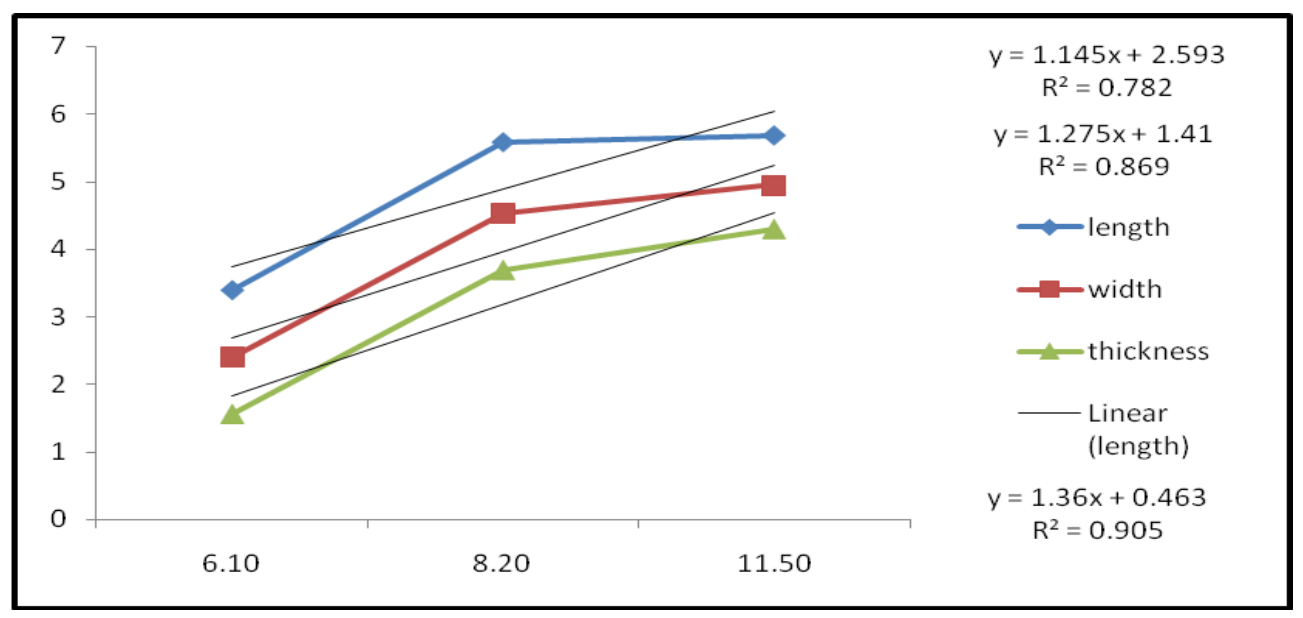


Fig.5 Effect of moisture content on porosity

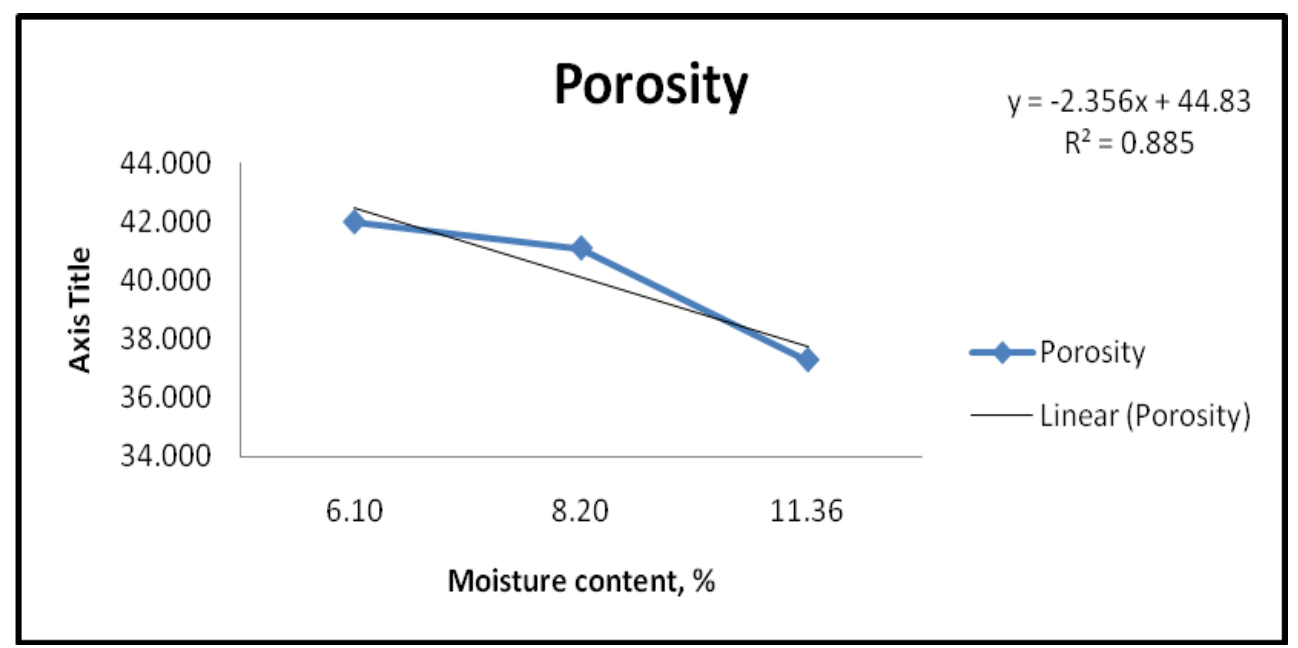

Fig.6 Effect of moisture content on angle of repose

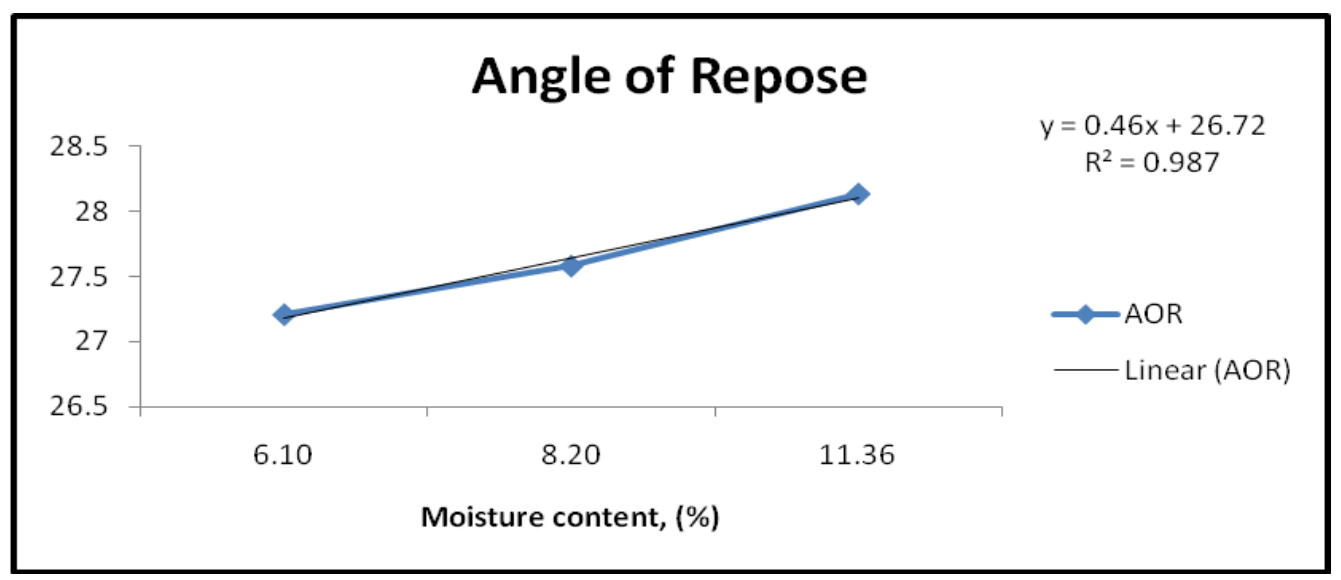

In figure 4 shows that the effect of moisture content on length, width, and thickness. The seed dimension was increased as well as moisture content increased. The existing relationship between moisture content and seed dimension. The value of $\mathrm{R}^{2}$ of length, width, and depth were $0.782,0.869$, and 0.905 respectively.

Figure 5 shows that the porosity decreased with increased moisture content. the correlation between porosity and moisture content. The value of $\mathrm{R}^{2}$ is 0.885 .

Figure 6 shows that the angle of repose was increased as well as moisture content was increased. The regression coefficient of the angle of repose was 0.987 .

The following conclusion is revealed from this study on the physical property of okra seeds for the moisture content with a range of $6.10 \%$ to $11.16 \% \mathrm{~dB}$.

It was found that the length, width, and thickness of okra seed increased with increases in moisture content.

The bulk density, true density, and porosity were decreased with increases in moisture content.

The angle of repose was increased as well as an increase in moisture content. 


\section{References}

Chakraverty A. Handbook of postharvest technology: Cereals, fruits, vegetables, tea, and spices. CRC Press, Boca Raton, United States of America; 1981.

Kumar V, Rani V, Jain M, Kumar A, Kumar S and Naresh, (2018). A study on physical properties of okra seed: Abelmoschus esculentus (L.), Advances in Research, 14(3).

Kushwaha HL, Srivastava AP, Singh H. A study on physical properties of okra pod and seed. Journal of Agricultural Engineering. 2007;44:88-91.
Mohsenin NN. Physical properties of plant and animal materials (2nd edn.). Gordon and Breach Science Publications, New York; 1986.

Sahoo PK, Srivastva AP. PH-postharvest technology: Physical properties of okra seed. Biosystems Engineering. 2002; 83(4):441-448.

Singh N, Singh DK, Pandey P, Panchbhaiya A, Rawat M. Correlation and path coefficient studies in okra [Abelmoschus esculentus (L.) Moench]. Int. J. Curr. Microbiol. App. Sci. 2017; 6(7):10961101.

\section{How to cite this article:}

Falguni Rathore and Atul Kumar Shrivastava. 2021. Determination of Various Physical Properties of Okra Seeds. Int.J.Curr.Microbiol.App.Sci. 10(02): 3575-3582.

doi: https://doi.org/10.20546/ijcmas.2021.1002.394 